\title{
A STRATIGRAPHIC SEQUENCE OF SIX THOUSAND YEARS \\ Preliminary report on the rescue excavation at the site of the former Óbuda Distillery (BUSZESZ)
}

Gábor Szilas ${ }^{1}$ - Tibor Budai Balogh ${ }^{2}$ - Barbara Hajdu ${ }^{3}$ - Viktória Kisjuhász ${ }^{4}$ - Adrienn Papp 5 - Nóra Szabó ${ }^{6}$

Hungarian Archaeology Vol. 9 (2020), Issue 4, pp. 1-13. doi: https://doi.org/10.36338/ha.2020.4.6

Árpád period pit houses with a stone oven, Roman period brick graves and a public bath, debris from Middle Bronze Age buildings, an Early Bronze Age cemetery, and Late Copper Age clay pit complexes - the thousands of archaeological features that appeared one below the other in a several metres thick stratigraphic sequence, and the nearly thousand boxes of finds are only one side of the coin. The other is represented by the constant roar of the machines, the deafening noise and the dust clouds from the pneumatic drill, the rhythmical sound of the suburban railway, the hubbub of construction workers, and the tight archaeological deadlines. At the site of the former Óbuda Distillery, during the almost three years of test and rescue excavations, we have encountered nearly all known elements of urban archaeology. We also appreciate that, in spite of the difficulties, we were given a unique, extraordinary and perhaps unparalleled opportunity. The site, after all, lies at the edge of the historical cores of the Roman Military Town and medieval Óbuda. The excavation site is noteworthy not only in terms of its vertical but also its horizontal extent. Following the highly informative period of fieldwork, hopefully we can begin the analysis as soon as possible, through which we may understand, step by step, the significance of this special place, where, until now, there lay the stratigraphic sequence of six thousand years of human presence.

\section{GENIUS LOCI - THE RECENT PAST AND RESEARCH HISTORY OF THE SITE}

The area in the Third District of Budapest, enclosed by Bogdáni Road, Folyamőr Street, Laktanya Street and the HÉV suburban railway line to Szentendre, is a busy, central part of Óbuda, with a prominent role in the history of industrialisation in the capital, which took off following the Austro-Hungarian Compromise of 1867. It was here on this site that Jakab Deutsch established in 1867 a factory producing industrial alcohol, which, under Vilmos Leipziger, became the largest manufacturer of alcohol and vinegar in the country by the turn of the century (Fig. 1). Industrial production, after constant reorganisations, only came to an end at the beginning of the 2010s. The new owner began the demolition of the plant buildings in 2016. In view of all this, it is by no means surprising that archaeological finds of varying source value have been coming to light here for some 150 years now. Consequently, the

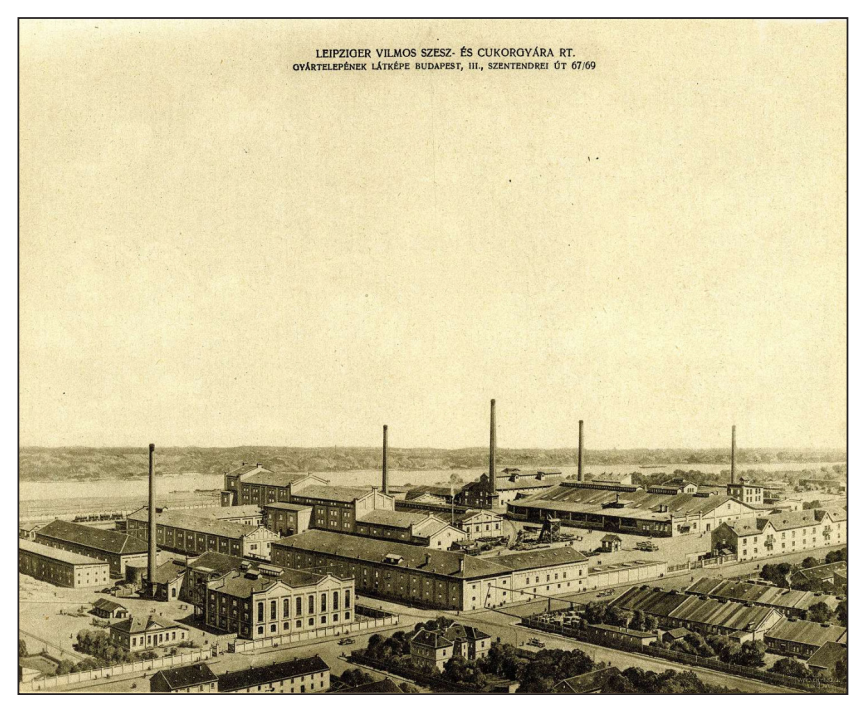

Fig. 1. The Vilmos Leipziger Alcohol and Sugar Factory, Ltd. plant in 1930. Metropolitan Ervin Szabó Library, Reg. no.: bibFSZ01472071

\footnotetext{
Archaeologist, Head of Department, BHM Aquincum Museum, Department of Prehistory and the Migration Period. E-mail: $\underline{\text { zzilasg@gmail.com }}$

Archaeologist, BHM Aquincum Museum, Department of Ancient History. E-mail: budaibalogh@yahoo.com Archaeologist, BHM Aquincum Museum, Department of Ancient History. E-mail: hajdubarbi91@,gmail.com Archaeologist, BHM Aquincum Museum, Department of Prehistory and the Migration Period. E-mail: kisjuhaszv@gmail.com Archaeologist, BHM Aquincum Museum, Medieval Department. E-mail: adry.papp@gmail.com

6 Archaeologist, ELTE Institute of Archaeological Sciences. E-mail: szabonori91@gmail.com
} 


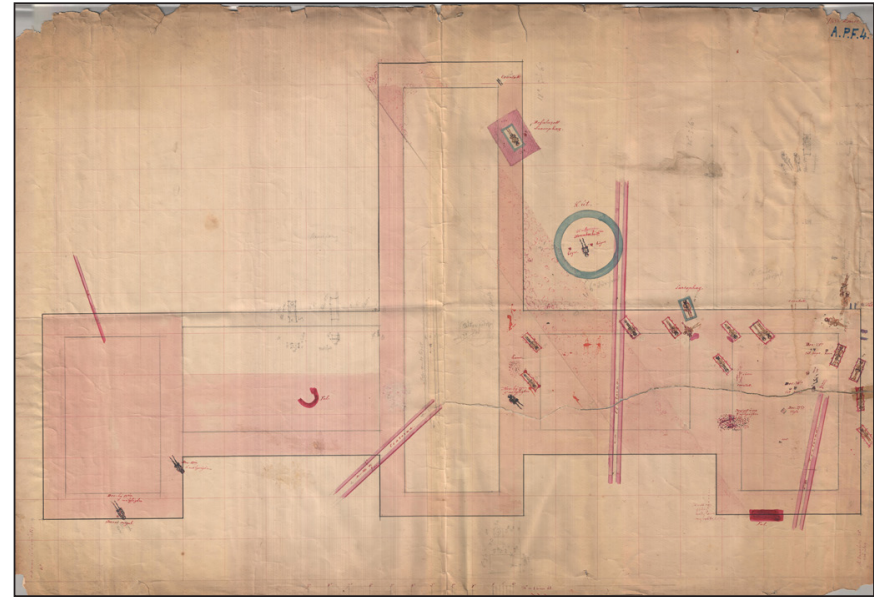

Fig. 2. The first graves found at the eastern cemetery, on the site of the later 'central hall' (the 1868 excavation of Flóris Rómer; summary plan (watercolour) by Gusztáv Zsigmondy, BHM Aquincum Museum, Drawings archive)

archaeological significance of the site had been well known among specialists also before the trial excavation in 2017 (GYURICZA 2008, 2-5).

The first pieces of information on the prehistoric remains at the multi-period site come from the final third of the 19th century. While later rescue works and excavations mostly studied the Roman settlement conditions, the Late Copper Age, Late Bronze Age, and Early and Late Iron Age finds uncovered suggest an intensive prehistoric occupation in the area (HAVAS 1892, 18; NAGY G. 1904, 111; NAGY L. 1937, 261; KABA 1984, 457: no. 2; KÖSZEGI 2000, 64, 81).

It was at the beginning of the plant's construction (1868) that the first Roman period graves, too, were brought to light (RÓMER 1868, 41-44, 65-68, 91-94; Fig. 2). Their continual discovery (KuZSINSZKY 1897a, 102; KuZSINSZKY 1897b, 403) even led some to suspect for a short time that the entire area of the Distillery may have belonged to the northern cemetery of the Aquincum Military Town (NAGY L. 1937, 266). Later on, however, more and more houses, building remains suggesting the presence of a baths, as well as street and sewer sections from the Military Town were uncovered in the southern half of the distillery premises (NAGY L. 1942, 359, 363; SzILÁGYI 1955, 403; KaBA 1976, 417: no. 86; Póczy 1983, 267).

Migration Period occupation was surmised based on Late Avar period pottery vessels, collected as stray finds (NAGY M. 1998, 39-40: FO 16), while prior to the start of the excavation series in 2017 medieval archaeologists suspected, also based on stray finds, (NAGY T. 1973, 212; FeHÉr, ÉRY \& KRAlovánszky 1962, 25: no. 110) a 10th century cemetery at the site of the Distillery.

With these in mind began in 2017, and continues to the present day, the most recent and most comprehensive research period of the site. As the first phase of the excavation series connected with the con- 
struction of a multifunctional housing estate, the test excavation led by Tibor Budai Balogh refined our previous understanding of the internal chronology of the site and the distribution of built remains. From it we also gained valuable data, indispensible for the planning of future research, regarding the site's stratigraphic context and the extent of disturbance (Budai BALOGH 2020).

Afterwards, in September 2018, began the series of rescue excavations, led first by Zoltán Havas and later by Gábor Szilas, moving from north to south immediately ahead of construction, in line with the development plan. The research completed until December 2020 comprised three major excavation phases, covering an area of around one hectare. There we unearthed - from at least fourteen phases belonging to nine archaeological periods (Fig. 3) - three and a half thousand archaeological features (Fig. 4) resulting in almost one thousand crates of finds. In terms of the degree to which the site - displaying a significantly higher than average intensity and complexity - can be researched, it is important to highlight that based on the test excavation's results, it is only in the southern half of the construction site that we may expect to find Roman period built remains in the context of the densely built Roman town worthy of preservation. Meanwhile, on the northern side we had - and have - an opportunity for the complete excavation of the entire stratigraphic sequence, relatively intact in spite of modern disturbance. Our research is also noteworthy in terms of its horizontal extent, as in the latter section we expect to be able to excavate a nearly contiguous area of $15000 \mathrm{sq}$ m until 2022

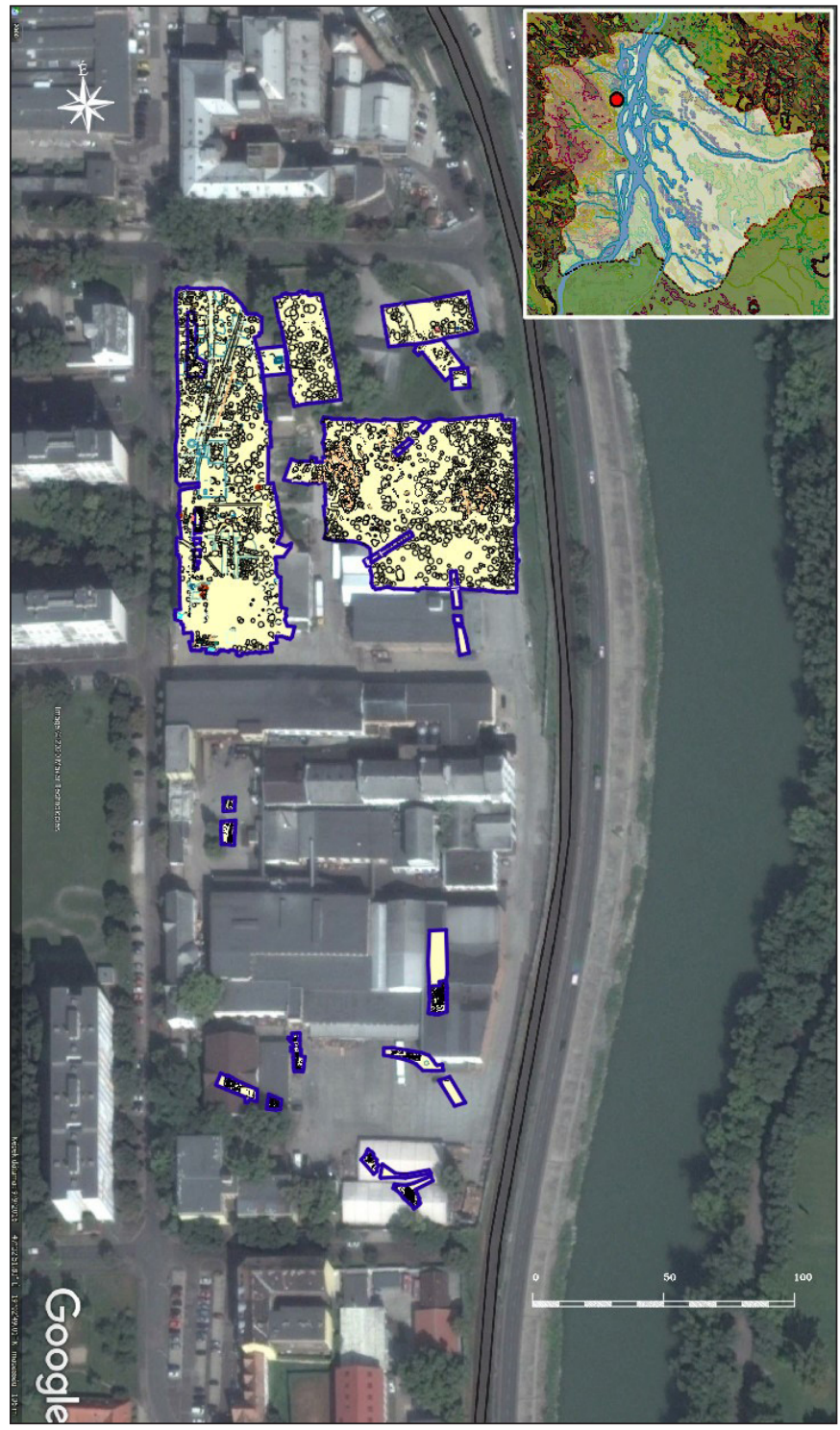

Fig. 4. Summary plan of the 2017-2020 excavations on the satellite image of the distillery premises (Geodetic survey by István Fábián, Tibor Kovács, Gergö Juhász, BHM Aquincum Museum) (Fig. 5). Nevertheless, during our work we are faced by significant methodological challenges. Although in terms of its size, budget and timeframe, ours belongs more to the category of open area excavations, we have to carry out the complete investigation - while meeting professional standards - of a deeply stratified site characteristic of historic town centres. Our goals, naturally, can only be reached through the efficient work of a team: of archaeologists, archaeological technicians, surveyors responding quickly to developments at the dig, and colleagues carrying out on-site work (drone photography, sampling etc.) for scientific analysis. $^{7}$

\footnotetext{
We would like to thank archaeologist Flóra Lamm, archaeological technicians Alfred Falchetto, Ferenc Barna, Zsófia Kelemen, Dániel Langer, Eszter Solnay, Nikolett Schmidt, Balázs Szabó, Tícia Tóbel-Domonkos, draughtspersons Orsolya Kangyal and Tamás Lajtos, geodetic surveyors Tibor Kovács, István Fábián and Gergő Juhász, who helped us greatly with on-site documentation. Special thanks are due to metal detectorist Lajos Sándor for the countless valuable metal artefacts he found, to László Rupnik (ELTE) for the drone imagery, to Magdolna Vicze and Gabriella Kovács (Matrica Museum Százhalombatta) for micromorphological sampling, to István Viczián and János Balogh (ELKH Geographical Institute) for sedimentological and pedological sampling, and to all those who played an active, even if brief, role in the excavation.
} 


\section{THE SITE'S GEOMORPHOLOGICAL, PALAEOHYDROLOGICAL AND STRATIGRAPHIC CONTEXT}

Based on our environmental archaeological and geomorphological research, ever widening in scope, on the Danube bank in Óbuda (SzILAs et al. 2019), we can state that this area provided one of the most favourable conditions for settlement in the Budakalász-Óbuda bay microregion. Its former surface was partly composed of a terrace surface, on average $102.8 \mathrm{~m}$ above sea level (Baltic Sea), formed through incisions

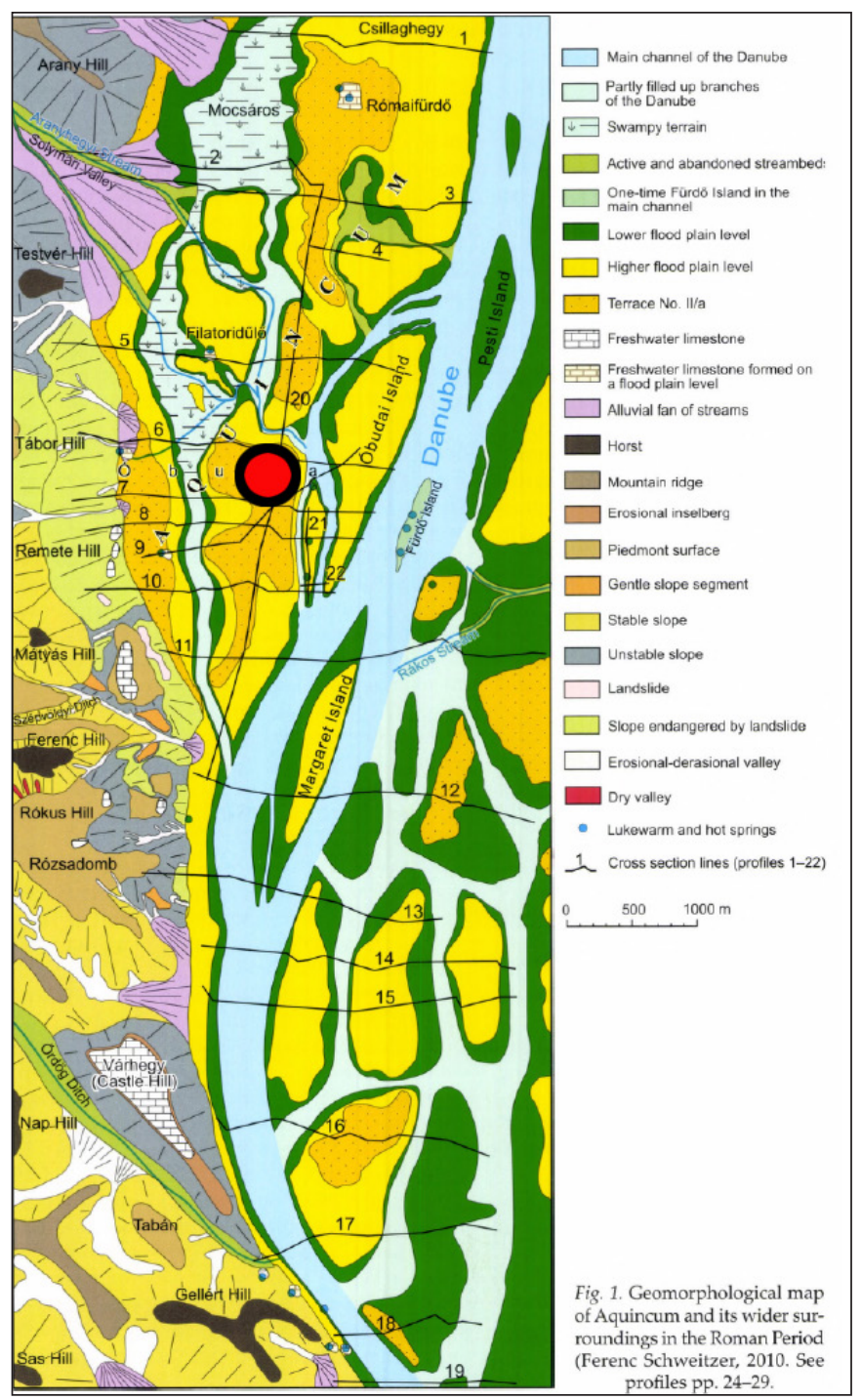

Fig. 5. Geomorphological map of the Budakalász-Óbuda bay, with the site of the excavation marked (based on H. KÉRDÖ \& SCHWEITZER 2010, Fig. 1) of the Danube during the Pleistocene. Its excellent position in terms of transport geography was underpinned by the relative proximity of the main branch of the river and the former mouth of the Aranyhegy Stream - localised at Filatorigát. At the same time, the zone of the neighbouring stretch of the main branch, punctuated by islands (Small and Large Óbuda Island), enhanced the defensive properties and economic potential of the area (Fig. 5).

At the excavation site itself, the stratigraphic context and the parameters of occupation in terms of space and time, are essentially defined by the presence of two geographical-morphological elements of different natures. In the 30-metre-wide strip in the west, we find a loessy-sandy terrain - the remains of terrace II/a mentioned above. Meanwhile, to the east, we see the zone of a so-called high floodplain (terrace I/b), sloping steeply at first then more gen-

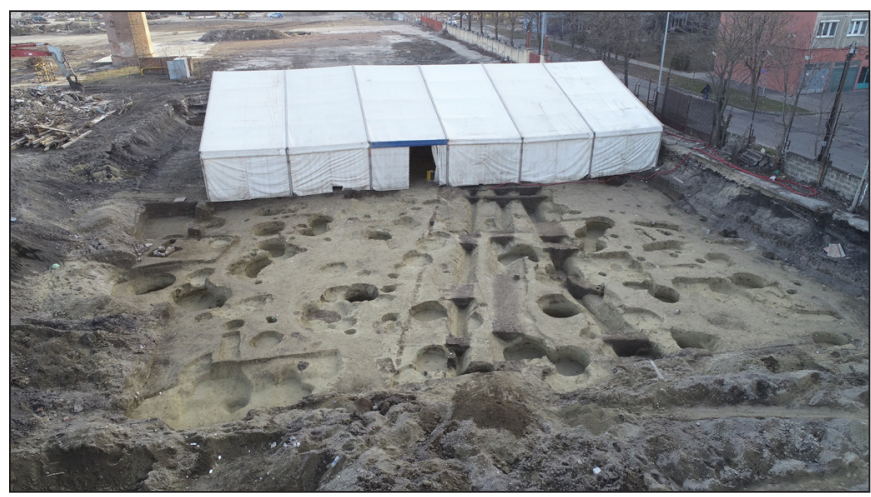

Fig. 6. Aerial photograph in winter 2018 of the trench opened in the higher, western strip of the site (Photograph by László Rupnik)

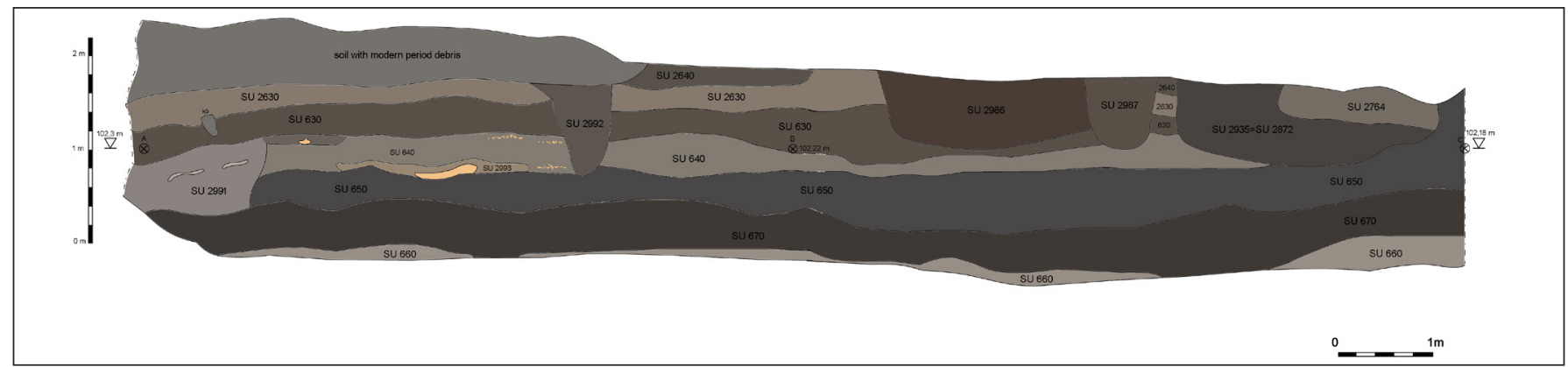

Fig. 7. Settlement layers in the western baulk of surface " $2 D$ ”. Section drawing. (Drawing by Orsolya Kangyal, BHM Aquincum Museum) 
tly, showing some minor unevenness, formed on a clayey-loessy subsoil. While at the former, we mostly found a 40-60 cm thick cultural layer (Fig. 6), the zone of the latter, similarly to the case of the riverbank by Békásmegyer, produced a greater number of layers, allowing us to document an archaeological stratigraphic sequence, 1.5-2 $\mathrm{m}$ in thickness, containing both larger horizontal and smaller local levels (Fig. 7).

\section{ARCHAEOLOGICAL PERIODS UNCOVERED DURING THE EXCAVATIONS}

The research is currently at the on-site documentation stage; therefore the data we have so far allows us to make inferences primarily about the topography. Nevertheless, some feature groups clearly have a greater significance beyond their immediate context.

\section{The millennia of Prehistory}

For now, we only have indirect data regarding the earliest human settlement at the site. The finds - secondarily washed into a sediment basin of natural origin at the eastern third of the high floodplain - from the Middle Neolithic (fragments with pinched ornaments and impressed knobs from the Notenkopf and Zseliz phases of the Transdanubian Linear Pottery Culture, ${ }^{8}$ 5300-5000/4950 B.C.) suggest the relative proximity of a contemporaneous settlement. We have a relatively large amount of data regarding the Neolithic settlement network of the riverbank by Csillaghegy-Békásmegyer north of our site (SzILAS \& VIRÁG 2017, 23-24.), and Neolithic occupation at the Danube islands next to our excavation can also be localised (KÉRDÖ \& VIRÁG 2006).

The Late Copper Age Baden Culture's (3500-3000 B.C.) pit complexes and refuse pits of various sizes primarily found in the thick, black clayey humus layer of the deeper eastern terrain - belong to a large settlement, which stretched for a long distance along the riverbank. Based on fresh observations, to the north the settlement can be traced as far as Filatorigát. ${ }^{9}$ From the fill of the settlement's pits, in addition to the large quantities of shell and fish scale remains - indicating the intensive exploitation of natural resources - we can highlight the intact bovine skeleton laid in a pit, which may be interpreted as the remains of a ritual documented at several places in this period. A similar, large settlement has also been found at the riverbank by Békásmegyer (LAMM \& SZILAS 2020, 19-26, ENDRŐDI 2002).

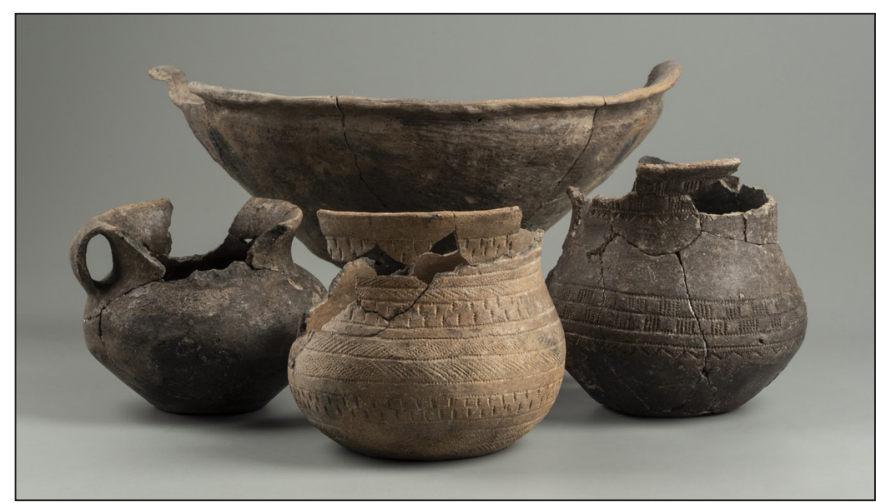

Fig. 8. Grave goods from the early Bronze Age Bell Beaker Culture - Csepel Group grave (Photograph by Nóra Szilágyi, BHM Aquincum Museum)

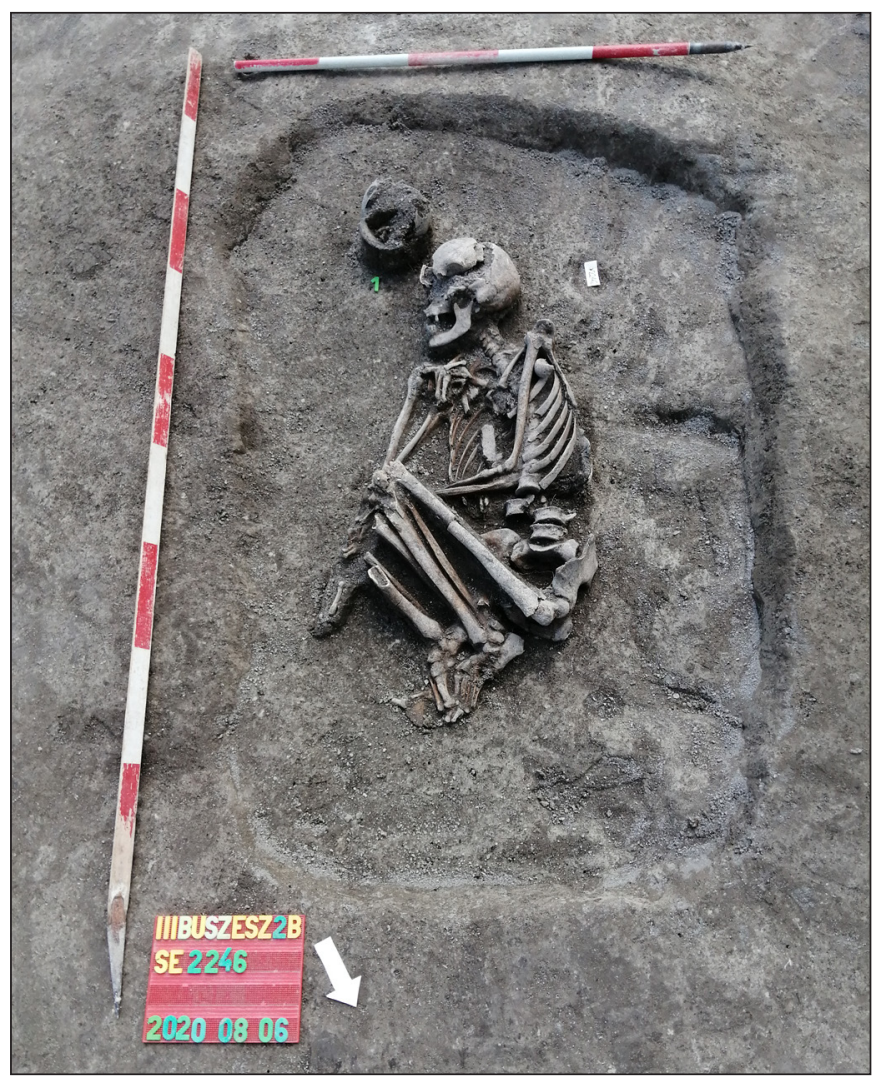

Fig. 9. Contracted inhumation of the early Bronze Age Bell Beaker Culture - Csepel Group (Photograph by Viktória Kisjuhász, BHM Aquincum Museum)

Zsuzsanna M. Virág, personal communication.

9 Excavation by Tibor Budai Balogh, 2017. 
In general, it can be said that the most intensive prehistoric occupation on the site appears during the Bronze Age, as indicated by the large number of settlement features as well as the nearly 1-metre-thick cultural layer, which also contains trodden surfaces and building debris. The section of a settlement established here during the Early Bronze Age by the Csepel Group of the Bell Beaker Culture (2500-2200/2100 B.C.) and a connected mixed-rite cemetery closer to the Danube to the east (Fig. 8-9) show the most complex prehistoric settlement structure at our excavation site. Suggesting a remarkably dense settlement network in this period is the fact that the chain of settlements and cemeteries dating to this period clearly also continues in the riverbank zone north of our site (Graphisoft Park: ENDRÖDI 2001). The interpretation - in addition to the beehive shaped storage pits of the settlement - of several post-rows and building debris as potentially Early Bronze Age post-structure constructions will only be possible following the detailed analysis of the find materials. Highly significant among the settlement features is a pit with a special, rectangular ground plan reflecting religious contexts. Through its unique stratigraphic sequence and finds as well as the deposited canine skeletons, it shows a close connection with a sacrificial pit of a similar design found in Szigetszentmiklós-Üdülősor in 1988 (ENDRÖDI 1992, 87, 98, 112, Fig. 6.100).

Connected with the Middle Bronze Age occupation - detected on the whole site from the Late NagyrévEarly Vatya period to the Late Vatya-Koszider period (2200/2100-1400 B.C.) - is a separate ashy-charcoaly layer with building debris covering the black ancient humus, indicating its importance. Based on the nature of the in situ features of this layer and the pits dug from it as well as the quality of the finds (Fig. 10 ) it is clear that we are in the central zone of a horizontal settlement of several hectares similar to Vatya sites along the Danube. In the northeastern section of the excavation site, we had a unique opportunity to excavate - on an area, enlarged with extensions, of $19 \times 8$ metres - a multi-period building complex with upstanding walls dated to the later phase of the Vatya

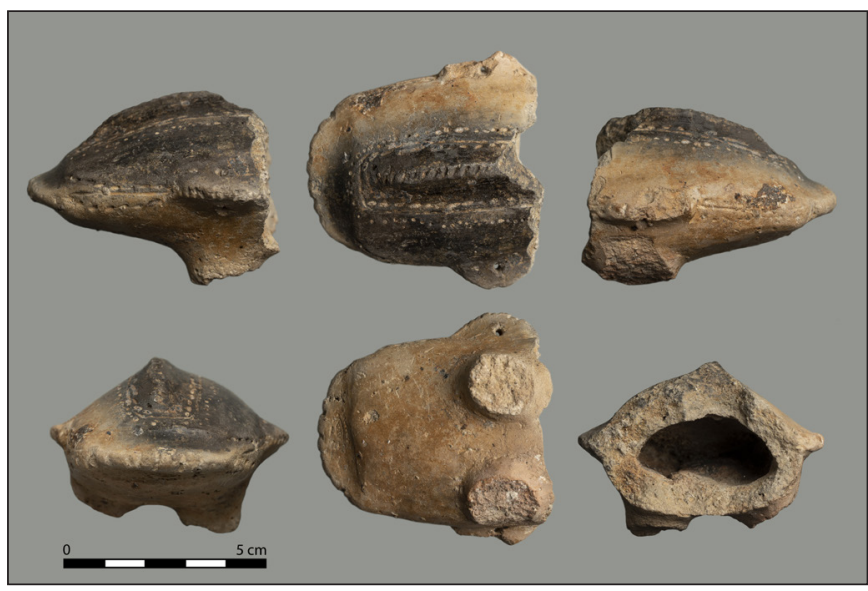

Fig. 10. Middle Bronze Age bird shaped rattle fragment (Photograph by Nóra Szilágyi, BHM Aquincum Museum) Culture. During the excavation of the building debris, some $40 \mathrm{~cm}$ in thickness, we were able to document roof and side wall remains. Underneath, we found the repeatedly renewed floors of the houses, the traces of hearths and other fixtures, and, impressed in the substratum, the structure of postholes for the beams holding the roof

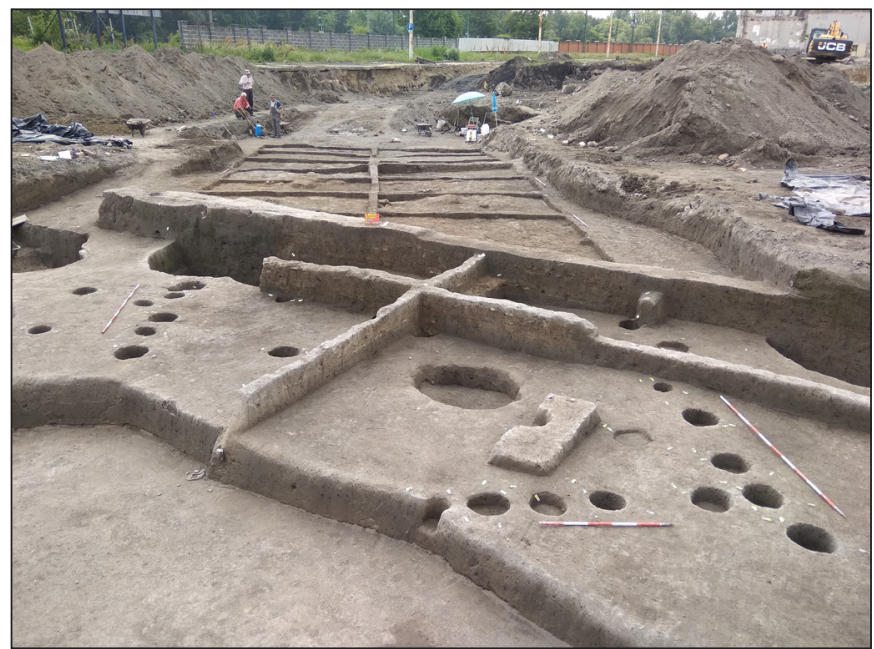

Fig. 11. Middle Bronze Age post-structure building during excavation (Photograph by Gábor Szilas, BHM Aquincum Museum) and forming the wall fabric also became clearly visible (Fig. 11). From this period, similar observations until now could only be made at the Culture's central, fortified, multi-layer tell settlements (Bölcske: Poroszlai 1992, 144, Százhalombatta: Vicze 2013); we have very little information concerning the architecture of so-called horizontal settlements. From the fill of the houses we systematically collected a large amount of soil samples for archaeobotanical, pollen, and phosphate analysis; we also took micromorphological samples from the floors' materials. Through their joint analysis, in co-operation with the Matrica Museum of Százhalombatta, we would also like to create the architectural historical reconstruction of the buildings.

In addition to the traces suggesting the presence of buildings, we observed another highly intriguing 
Gábor Szilas et al. • A Stratigraphic Sequence of Six Thousand Years

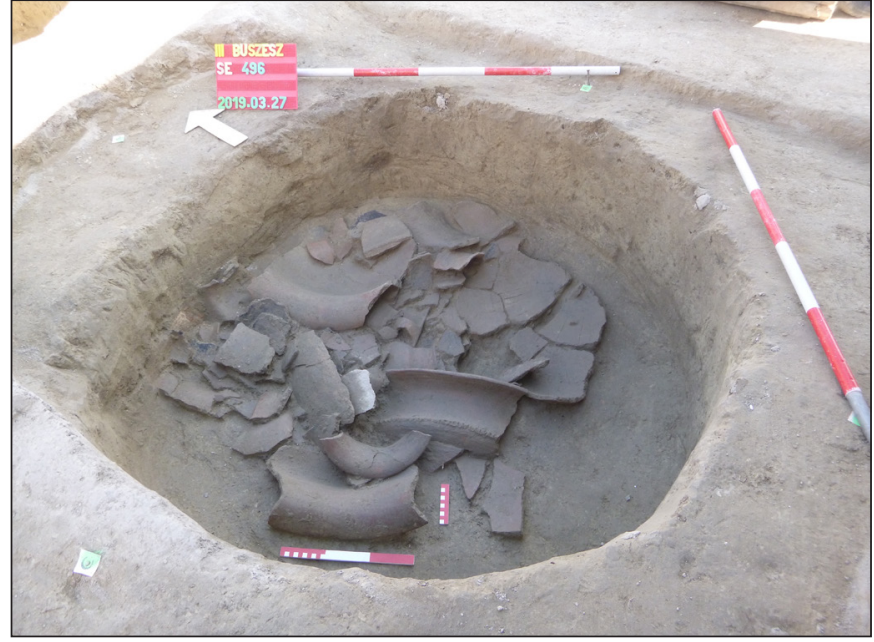

Fig. 12. Middle Bronze Age vessel depot, final phase of excavation (Photograph by Gábor Szilas, BHM Aquincum Museum) settlement feature. At several points of the site, in six cases altogether, we found pits containing large amounts of pottery fragments placed one above the other in multiple layers (Fig. 12). These are notable given the quantity of the finds as well as the composition of the vessels based on function and the secondary burn marks observed on them (deformed, blistered surfaces). Examination of the aforementioned six cases shows that storages vessels are clearly in the majority. In addition to urn shaped vessels and deep bowls we also found there vessels with a knobbed, ribbed and rusticated inside surface, used for the fermentation of dairy products or alcoholic beverages. The feature is special, though not completely unique. After all, vessels in a similar situation have been found also at the Middle Bronze Age horizontal settlement at Budajenő - Hegyi-szántók

(GuCsI \& SzABó 2018). The placing of the assemblages in such a state in the pit was, in all likelihood, the result of a deliberate choice. Therefore, in our opinion, what we observed too belonged to the vessel deposition practice which can be documented throughout the Bronze Age - although the composition, characteristics and reasons of deposition were rather varied depending on the period and cultural environment (Kalla, Raczky \& Szabó 2013, 24). Although the Middle Bronze Age vessel depots documented were primarily beaker assemblages (SCHREIBER 1967, 49; KovÁcs 1978, 221; P. Fischl, Kiss \& KulcsÁr 1999, 77), open area excavations in recent years have shown that the deposition trend which also features storage vessels - pointing towards the Late Bronze Age - can be observed at settlements already in this period (V. SzABÓ 2004, 86; ILON 2010, 19-30.).

The Late Bronze Age settlement section documented at the BUSZESZ site has an important place in the reconstruction of the Urnfield settlement concentration - with iconic Urnfield assemblages to the south of our site at Flórián Square (KöszEGI 1996) and Harrer Pál Street (Köszegr 1984) and with Urnfield settlement traces observed in multiple places north of our site at Filatorigát (ZsIDI 2001, 60.) characteristic of the Late Bronze Age (1200-800 B.C.) settlement network on the right bank of the Danube. The pit complexes with rich finds (graphite slipped polished ware, grated oven baking surface and andiron fragments, flange-hilted bronze sword (Fig. 13), and arrowhead) and the remains of poststructure buildings characteristic of the Urnfield period documented between them are clearly clustered in the higher, western terrain. The zone of the eastern high floodplain in this period shows only sporadic occupation.

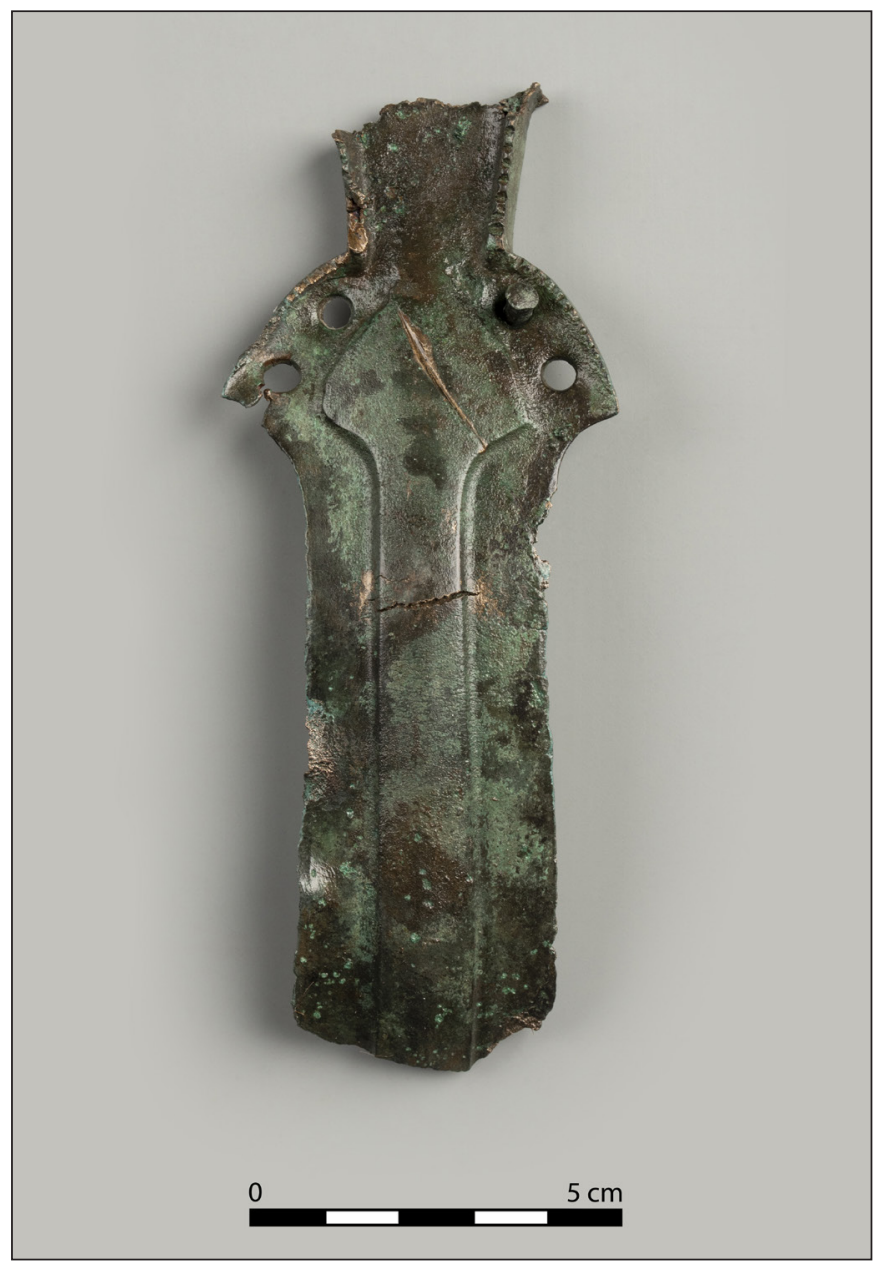

Fig. 13. Late Bronze Age flange-hilted sword fragment (Photograph by Nóra Szilágyi, BHM Aquincum Museum) 
The settlement consisting of units with storage pits and pit houses and containing find materials characteristic of the Early-Middle Hallstatt Culture (800-450 B.C.) is unambiguously concentrated - as in the previous period - in the area which includes the remains of the higher terrace II/a. The observations made here fit well into the settlement strategy of the Early and Middle Iron Age. A site of similar intensity has also been found to the north along the Danube.

By the Late Iron Age, the entire width of the riverbank section under investigation became settled. The finds from the village-like Celtic settlement's pit houses and storage and refuse pits (Fig. 14) can be dated to the La Tène C2-D1 (180-60 B.C.) period.

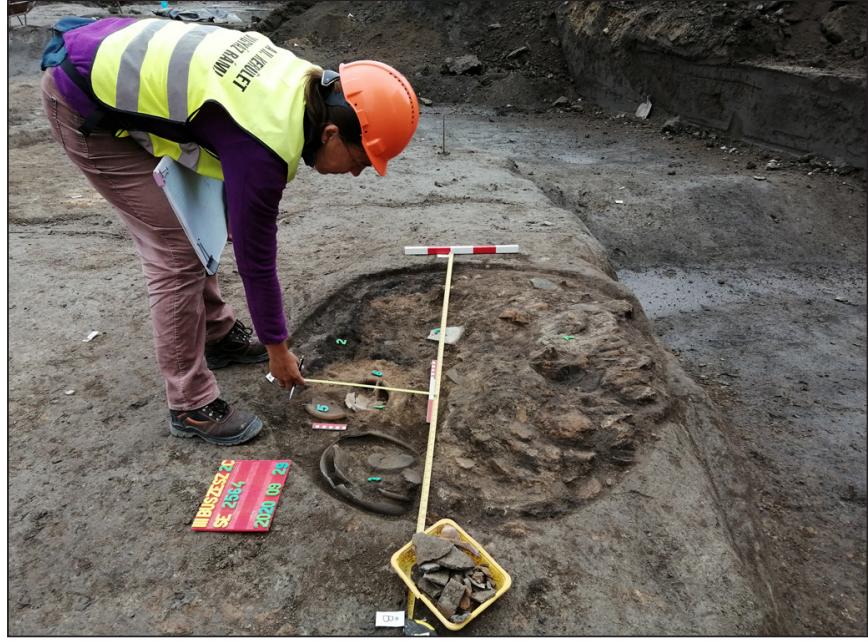

Fig. 14. Late Iron Age refuse pit during documentation (Photograph by Gábor Szilas, BHM Aquincum Museum)

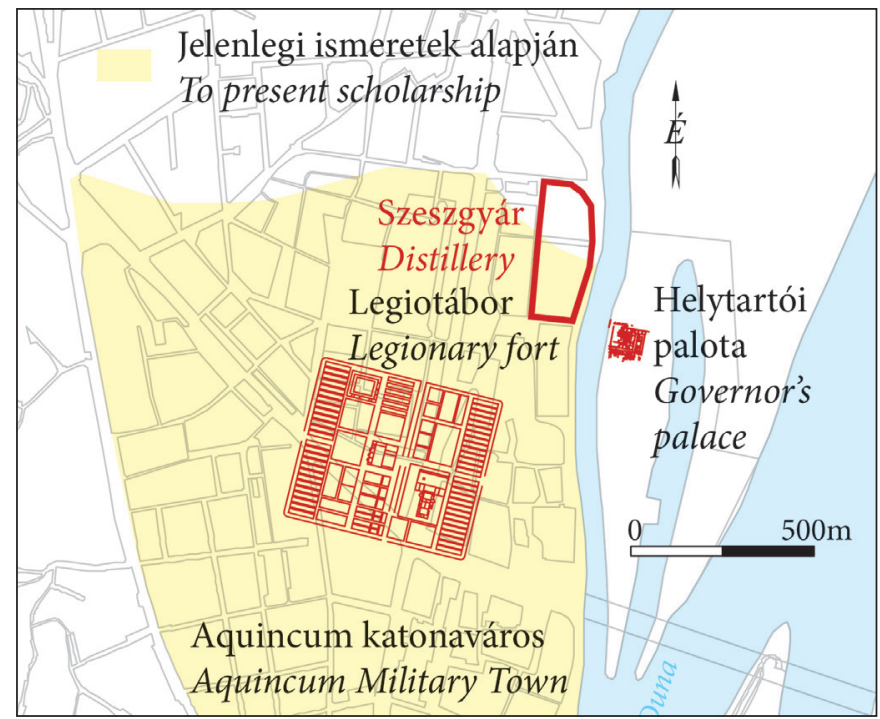

Fig. 15. The location of the former Óbuda distillery on the map with the ancient topography (Map by Krisztián Kolozsvári, BHM Aquincum Museum) that the investigated strip of the town's northeastern corner was destroyed in the final third of the 3rd century, never to be rebuilt. Occupation, however, did not cease in the 4th century either. As seen in other parts of the town, the buildings and gardens of the abandoned quarter came to be used as a cemetery by the population which withdrew to the town centre. The Late Roman use of this suburban area, however, included a rather curious feature. This appeared in the form of a buttressed wall, constructed across a dwelling house which had been pulled down deliberately and filled in, postdating all building periods of the house. The possibility that the Distillery site or its surrounding area came to be used for military purposes is raised by the stamped bricks of Frigeridus, commander of the border forces (dux Valeriae ripen-

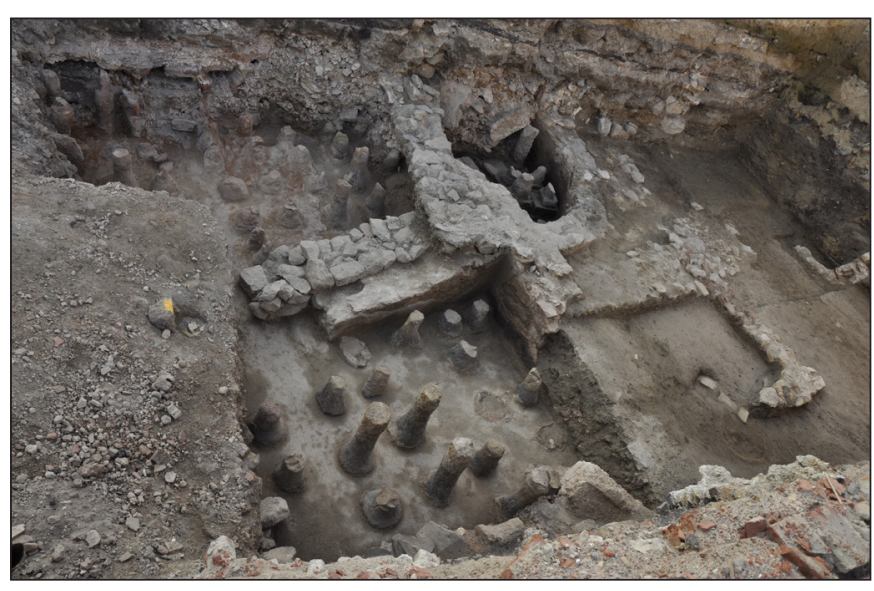

Fig. 16. A section of rooms with underfloor heating at the Roman public baths (Photograph by Nóra Szilágyi, BHM Aquincum Museum) 
sis: AD 371-373/374), and other officers found at the cemeteries located in the northern half of the distillery premises (Fig. 17). It cannot be precluded that the site clearance and the raising of the buttressed structure were also connected with the border reinforcement programme during the Valentinian period; although a definitive answer requires further research.

While small scale sondage in the southern half of the distillery premises only allowed for a limited analysis of the latest building periods of the Military Town, the systematic excavation of the northern half, launched in 2018, revealed the complete periodisation of extra-urban land use. Three large semi-subterranean houses represent the earliest period (end of the 1st century - beginning of the 2nd century A.D.). In spite of the Iron Age lifestyle and housing culture, the finds in these buildings are all provincial products, including some more expensive vessel types, while traditional Celtic products are completely absent. A broken amphora lying on the floor may serve as an indication of the Mediterranean taste taking hold among the local population also in terms of gastronomy. The full analysis of the finds will provide the probable date when this small settlement was abandoned - likely at the end of earliest period of the Military Town and the establishment of the provincial capital.

Afterwards, in the western strip of the site a complex system of ditches and a row of wells were dug for agricultural use (animal husbandry). In the fill of the ditches - which cut through the earlier settlement features - and the wells, we uncovered finds from the second-third centuries A.D.

The eastern strip of the site, from the middle third of the 3rd century the latest, came to function as a cemetery stretching north along a main road leading from the town, built on the bank of the Small Danube branch. The cemetery was disturbed already in 1868 , with the start of construction works on the plant. Based on our observations so far, at least three grave horizons can be identified in the cemetery according to the stratigraphy, orientation and grave type. The latest, 4th century gracile skeletons differ also in terms of anthropology from members of the earlier robust populace.

In the western strip of the site, distinct grave groups appeared in the Late Roman period. At the cemetery section in the northwestern corner of the distillery premises, we found, in addition to simple earth graves, partial stone cist graves and brick

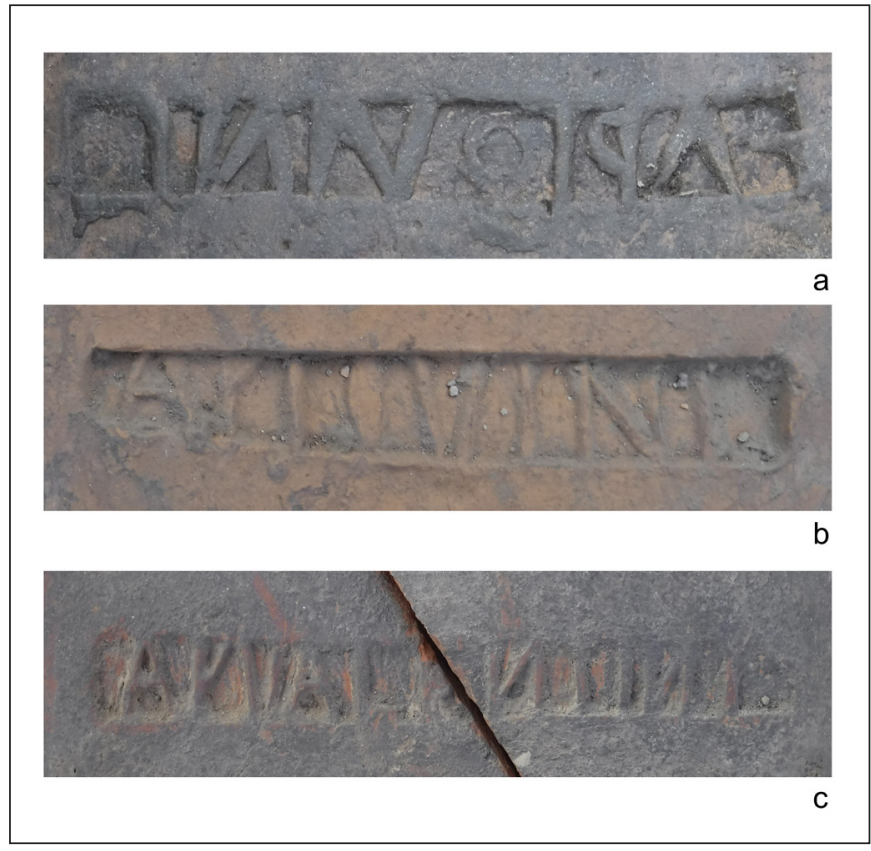

Fig. 17. Brick stamps dating to the tenure of Frigeridus dux (Photograph by Tibor Budai Balogh, BHM Aquincum Museum)

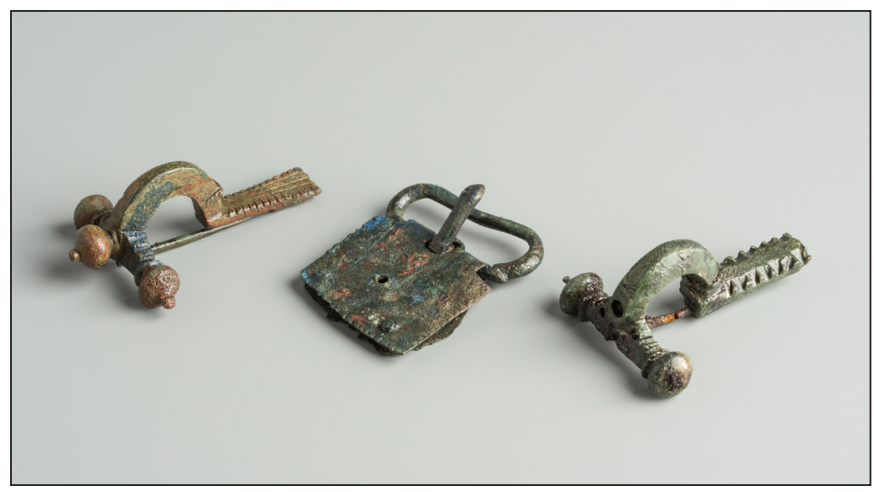

Fig. 18. Dress elements from the northwestern grave group of the excavation site (Photograph by Nóra Szilágyi, BHM Aquincum Museum)

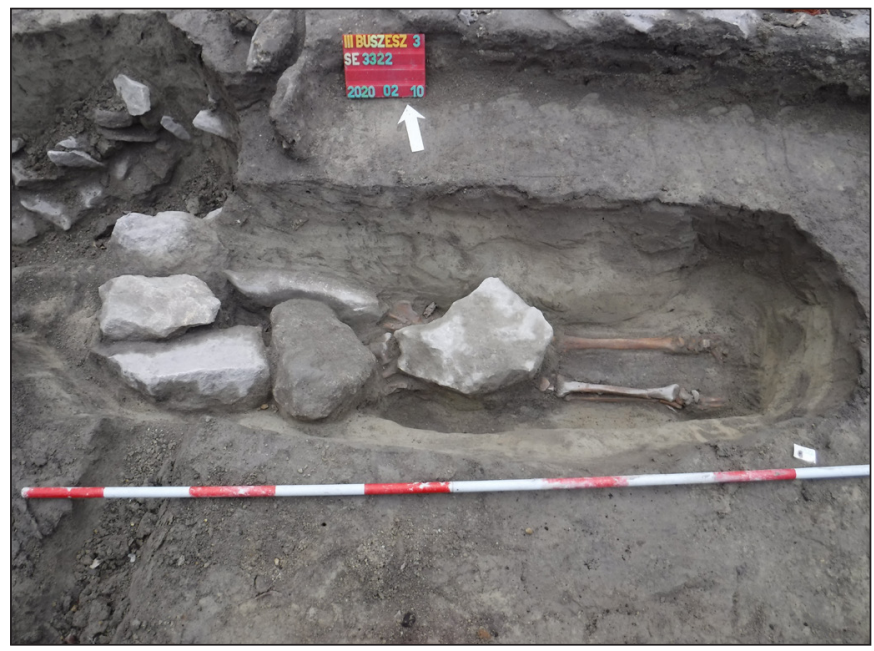

Fig. 19. Deviant burials in the southern grave group (Photograph by Tibor Budai Balogh, BHM Aquincum Museum) 
graves as well. The graves are dated by characteristic 4th century artefacts - silvered belt buckle, cross-bow brooches (Fig. 18). This grave group is separated by a system of ditches from another 4th century burial ground to the south, which contained at least three grave horizons. The earliest of these is roughly contemporaneous with the latest graves of the eastern cemetery and can be connected with the gracile-framed populace seen there. The latest grave was built using stamped bricks dating to the tenure of Frigeridus $d u x$; based on the grave goods it may not belong to much later than the Valentinian period. The southern grave group stretches towards the town, becoming denser.

In the cemeteries discovered at the site of the distillery, the ratio of deviant burials - connected with ghost belief or punishment - is unusually high. The two kinds of motivation manifest in essentially the same procedure: keeping down the corpse - physically (with stones or bricks) or symbolically (with an iron nail or a human skull placed on the corpse) - or tying up the dead body (Fig. 19). Those punished - as evil dead, likely to haunt - were buried outside the grave group, far from the 'decent people', weighed down or tied up. Exclusion could also be emphasised at times by the different orientation or greater depth of the grave, or the face down burial of the corpse.

The cemetery sections uncovered so far only provide us limited insight concerning the relationships between the individual grave groups. Cemetery investigation on a larger scale will be possible from the next excavation season.

\section{Árpád period village}

It took us all by surprise when we uncovered a section of an early Árpád period village at the BUSZESZ site, otherwise unattested in charters, which lay at the edge of two historic town centres. The ruins of ancient Aquincum were still visible, and in the 11th century the first large churches and stone buildings had already been erected in the town referred to at the time in medieval charters not as 'Old' Buda (Óbuda), but as Buda/Budavára. On account of 19th and 20th century disturbances, the village - which also stretched over the 4th century cemetery - could only be documented in patches. In the several dozen semi-subterranean, rectangular pit houses with an average floor space of $3 \times 2.5 \mathrm{~m}$, the stone-built ovens used for heating were established in the northeastern corner. The oven dome was preserved intact in two cases. The semisubterranean ovens - in multiple cases equipped with a working hollow - and food storage pits between the buildings provided the majority of the relatively poor find material. Of these we can highlight sherds of pots characteristic of this period and a coin, based on which the village was established in the 12th century.

\section{BIBLIOGRAPHY}

Budai Balogh, T. (2020). Sörgyári capriccio. Topográfiai kutatások az aquincumi canabae északkeleti határában (Capriccio in a distillery. Topographic research on the northeast border of the Aquincum canabae). Aquincumi Füzetek 24, in press.

Endrődi, A. (1992). A korabronzkori Harangedény kultúra telepe és temetője Szigetszentmiklós határában (The settlement and cemetery of the Bell-Beaker Culture in the district of Szigetszentmiklós). In Havassy P. \& Selmeczi L. (eds.), Régészeti kutatások az M0 autópálya nyomvonalán I. - Archaeological Researches on the Line of Motorway MO Vol. 1 (pp. 83-200). BTM Mühely 5. Budapest: Budapest Történeti Múzeum.

Endrödi, A. (2001). Korabronzkori sírok Aquincum körzetében (Early Bronze Age graves in the environs of Aquincum). Aquincumi Füzetek 7, 85-88.

Endrődi, A. (2002). Adatok Békásmegyer őskori településtörténetéhez (Facts concerning the prehistoric settlement history of Békásmegyer settlements and burial-places of the Baden culture from the late Copper Age). Budapest Régiségei 35 (1), 35-75. 
Fehér, G., Éry, K. \& Kralovánszky, A. (1962). A Közép-Duna-medence magyar honfoglalás és kora Árpádkori sírleletei. Leletkataszter [Grave Finds of the Hungarian Conquest and the Early Árpád Period. Register of Finds]. Régészeti Tanulmányok II. Budapest: Akadémiai Kiadó.

P. Fischl, K., Kiss, V. \& Kulcsár, G. (1999). Kora és középső bronzkori település Baks-Homokbánya (Csongrád megye) lelöhelyen (Früh- und mittelbronzezeitliche Siedlungen auf dem Fundort BaksHomokbánya (Komitat Csongrád). A Móra Ferenc Múzeum Évkönyve 5, 77-190.

Gyuricza, A. (2008). Budapest, III., Bogdáni út - HÉV-vonal - Sorompó utca - Folyamőr utca mindkét oldala (a megszünő BUSZESZ területén kívül a Szentendrei útig húzódó lakótelep területe is) által határolt terület kerületi szabályozási tervéhez szükséges örökségvédelmi hatástanulmány régészeti fejezete [Archaeological chapter of the heritage protection impact study required for the local government regulation plan for the area enclosed by Bogdáni Road, the HÉV suburban railway line, Sorompó Street, and Folyamőr Street (also including the housing estate stretching to Szentendrei Road, in addition to the premises of the closing BUSZESZ) in the Third District of Budapest]. Manuscript.

Gucsi, L. \& Szabó, N. (2018). Examination and possible interpretations of a Middle Bronze Age structured deposition. Dissertationes Archaeologicae 3 (6), 217-286. https://doi.org/10.17204/dissarch.2018.217

H. Kérdő, K. \& Schweitzer F. (eds.) (2010). Aquincum. Ancient Landscape - Ancient Town. Theory Method - Practice 69. Budapest: Geographical Institute, Research Centre for Astronomy and Earth Sciences, Hungarian Academy of Sciences.

Havas, S. (1892). Visszapillantás az 1889-1892. évek eseményeire. A főváros budai részének régi topographiája [A review of the events of the years 1889-1892. The old topography of the Buda part of the capital]. Budapest Régiségei 4, 3-30.

Ilon, G. (2012). A halomsíros kultúra rituális „edénydepója” Veszprém határából. - The ritual „vessel hoard” of the Tumulus culture in the vicinity of Veszprém. In J. Kisfaludi (ed.), Régészeti kutatások Magyarországon 2010. - Archaeological Investigations in Hungary 2010 (pp. 19-53). Budapest: Kulturális Örökségvédelmi Hivatal - Magyar Nemzeti Múzeum.

Kaba, M. (1976). A Budapesti Történeti Múzeum ásatásai és leletmentései 1971-1975 között [Rescue excavations of the Budapest History Museum n 1971-1975]. Budapest Régiségei 24 (1), 393-444.

Kaba, M. (1984). A Budapesti Történeti Múzeum ásatásai és leletmentései 1976-1982 között [Rescue excavations of the Budapest History Museum n 1976-1982]. Budapest Régiségei 25, 455-502.

Kalla, G., Raczky, P. \& V. Szabó, G. (2013). Ünnep és lakoma a régészetben és az írásos forrásokban. Az öskori Európa és Mezopotámia példái alapján [Festival and feast in archaeology and the written sources, based on examples from prehistoric Europe and Mesopotamia]. In B. Déri (ed.), Convivium. Az Eötvös Loránd Tudományegyetem Bölcsészettudományi Karán 2012. november 6-7-én tartott vallástudományi konferencia elöadásai (pp. 11-46). Budapest: ELTE BTK Vallástudományi Központ.

Kérdő, K. \& M. Virág, Zs. (2006). Régészeti megfigyelés az Óbudai (Hajógyári)-szigeten (Archaeological observations of Óbuda (Dockyard) Island). Aquincumi Füzetek 12, 24-29.

Kovács, T. (1978). Középső bronzkori edénylelet Mogyoródról [A Middle Bronze Age pottery find from Mogyoród]. Archaeologiai Értesítö 105, 217-222. 
Gábor Szilas et al. A Stratigraphic Sequence of Six Thousand Years

Kőszegi, F. (1984). Késő bronzkori leletek a Harrer Pál utcából (Budapest, III. ker.) (Spätbronzezeitliche Funde aus der Harrer Pál utca). Budapest Régiségei 25, 121-134.

Köszegi, F. (1996). The bronze finds from Budapest-Flórián tér. In T. Kovács (Hrsg.), Studien zur Metallindustrie im Karpatenbecken und den benachbarten Regionen (pp. 175-181). Budapest: Magyar Nemzeti Múzeum.

Kőszegi, F. (2000). Öskor [Prehistory]. In Cs. Kiss \& F. Mócsy (eds.), Óbuda évszázadai (pp. 57-82). Budapest: Better Kiadó.

Kuzsinszky, B. (1897a). Az Aquincumi Muzeum és kőemlékei (az építészeti részek kihagyásával) [The Aquincum Museum and its stone monuments (excluding architectural elements)]. Budapest Régiségei 5, 95-164.

Kuzsinszky, B. (1897b). Az aquincumi castra kérdése [The question of the Aquincum castra]. Archaeológiai Értesitö 31, 395-405.

Lamm, F. \& Szilas, G. (2020). Újabb kutatások az egykori BUVÁTI üdülő területén (Recent Excavations in the area of the former BUVÁTI recreational establishment. Aquincumi Füzetek 24, in press.

Nagy, G. (1904). Budapest és vidéke az őskorban [The area of present-day Budapest and its environs in prehistory]. Budapest Régiségei 8, 85-157.

Nagy, L. (1937). Az Aquincumi Múzeum kutatásai és gyarapodása az 1923-35. években [Research and collection growth at the Aquincum Museum in the years 1923-35]. Budapest Régiségei 12, 261-275.

Nagy, L. (1942). Topografia. In Szendy K. (szerk.), Budapest története. Vol. I. 2 (pp. 353-385). Budapest: Királyi Magyar Egyetemi Nyomda.

Nagy, T. (1973). Budapest története az őskortól a honfoglalásig [Budapest and its surroundings from Prehistory to the Hungarian Conquest]. In L. Gerevich (ed.), Budapest története. Vol. 1 (pp. 39-216). Budapest: Akadémiai Kiadó.

Nagy, M. (1998). Awarenzeitliche Gräberfelder im Stadtgebiet von Budapest. Vol. I. Monumenta Avarorum Archaeologica 2. Budapest: Magyar Nemzeti Múzeum - A Magyar Tudományos Akadémia Régészeti Intézete.

Póczy, K. (1983). Az aquincumi canabae utcahálózata és fontosabb épületei a II. és a III. században (Das Straßennetz und die wichtigeren Gebäude der Militärstadt von Aquincum im 2. und 3. Jahrhundert). Archaeológiai Értesítö 110, 252-273.

Poroszlai, I. (1992). Bölcske-Vörösgyürü. In W. Meier-Arendt (Hrsg.), Bronzezeit in Ungarn. Forschungen in Tell-Siedlungen an Donau und Theiss (pp. 141-146). Frankfurt am Main: Museum für Vor- und Frühgeschichte.

Rómer, F. (1868). A legujabb ó-budai ásatások [The most recent excavations in Old Buda]. Archaeológiai Értesító 1, 41-44, 65-68, 91-94.

Schreiber, R. (1967). A rákospalotai edénylelet [The pottery find from Rákospalota]. Archaeológiai Értesitö 94, 54-58. 
V. Szabó, G. (2004). A tiszacsegei edénydepó. Újabb adatok a Tisza-vidéki késő bronzkori edénydeponálás szokásaihoz [(Das Gefäßdepot von Tiszacsege. Neue Angaben zur Sitte der spätbronzezeitlichen Gefäßdeponierung in der Theißgegend)]. A Móra Ferenc Múzeum Évkönyve 10, 81-113.

Szilas, G., Viczián, I., Sipos, Gy., Páll, D. G., M. Virág, Zs. \& Rekeczki, K. (2019). Környezetrekonstrukciós vizsgálatok az óbudai Duna-part mikrorégió területén [Environmental reconstruction research of the Óbuda Danube bank microregion]. In F. M. Tóth (ed.), MSMOL-Öskoros Kutatók XI. Összejövetele-Környezet és ember. Absztrakt kötet (p. 31). Budapest: Budapesti Történeti Múzeum.

Szilas, G. \& M. Virág, Zs. (2017). A nagy folyam vonzásában: többkorszakos őskori lelőhelyek láncolata az óbuda-békásmegyeri Duna-parton (Lured by the great river: a chain of multi-period prehistoric sites along the Óbuda-Békásmegyer section of the Danube). In P. Zsidi (ed.), Kincsek a város alatt - Újdonságok a múltból. Budapest régészeti örökségénekfeltárása 1867 /2005-2015 (pp. 21-26). Budapest: Archaeolingua.

Szilágyi, J.(1955). A rómaikori ásatások fontosabb eredményei Budapest területén és az Aquincumi Múzeum értékesebb gyarapodásai az 1951-53. években (Wichtige Ergebnisse römerzeitlicher Ausgrabungen im Gebiet von Budapest und wertvolle Bereicherungen des Museums in Aquincum in den Jahren 1951-1953). Budapest Régiségei 15, 387-426.

Vicze, M. (2013). Middle Bronze Age Households at Százhalombatta-Földvár. In A. Anders \& G. Kulcsár (eds.), Moments in Time. Paper Presented to Pál Raczky His 60 th Birthday (pp. 757-770). Budapest: Ösrégészeti Társaság - ELTE - L'Harmattan.

Zsidi, P. (2001). Településszerkezet kutatása az aquincumi katonavárostól északra (Research into the settlement structure north of the Aquincum Military Town). Aquincumi Füzetek 7, 59-67. 